УДК 629.463.083-027.45

\title{
ОСОБЛИВОСТІ ТЕХНІЧНОГО ОБСЛУГОВУВАННЯ ТА РЕМОНТУ ВАНТАЖНИХ ВАГОНІВ 3 ПІДВИЩЕНИМИ ПОКАЗНИКАМИ НАДІЙНОСТІ
}

\author{
Д-р техн. наук В.М. Бубнов, кандидати техн. наук Л.А. Мурадян, М.Б. Манкевич, \\ інж. В.Ю. Шапошник

\section{ОСОБЕННОСТИ ТЕХНИЧЕСКОГО ОБСЛУЖИВАНИЯ И РЕМОНТА ГРУЗОВЫХ ВАГОНОВ С ПОВЫШЕННЫМИ ПОКАЗАТЕЛЯМИ НАДЕЖНОСТИ}

\section{Д-р техн. наук В.М. Бубнов, кандидаты техн. наук Л.А. Мурадян, М.Б. Манкевич, инж. В.Ю. Шапошник \\ THE PECULIARITIES OF TECHNICAL SERVICE AND THE REPAIRING WITH RELIABILITY OF FREIGHT CARS}

Doct. of techn. sciences V. Bubnov, cand. of techn. sciences L. Muradian, N.B. Mankevych, engineer V. Shaposhnyk

У статті наведені особливості технічного обслуговування та ремонту вантажних вагонів з підвищеними показниками надійності. Пропонуються напрямки реформування вагонного господарства, які дозволяють знизити витрати на технічне обслуговування та ремонт вантажних вагонів. Запропоновані напрями враховують сучасні тенденції реформування вагонного господарства, такі як перехід від планово-попереджувальної системи ремонту до ремонту за фактичним станом, а також впровадження гнучких потокових систем на вагоноремонтному виробництві.

Ключові слова: планово-попереджувальна система ремонту, ремонт з урахуванням фактичного технічного стану, гнучкі потокові системи, вагони нового покоління.

В статье приведены особенности технического обслуживания и ремонта грузовых вагонов $c$ повыменными показателями надежности. Предложены направления реформирования вагонного хозяйства, которые позволяют снизить затраты на техническое обслуживание и ремонт грузовых вагонов. Предложенные направления учитывают современные тенденции реформирования вагонного хозяйства, такие как переход от планово-предупредительной системы ремонта к ремонту по фактическому состоянию, а также внедрение гибких поточных систем на вагоноремонтном производстве.

Ключевые слова: планово-предупредительная система ремонта, ремонт с учетом фактического технического состояния, гибкие поточные системы, вагоны нового поколения.

Peculiarities of technical service and the repairing with reliability of freight cars given in the article. The directions of car industry reforming are proposed which allow decreasing technical service expenses and repairing of freight cars. They include modern trends of car industry reforming such as changing of planning - warning repairing system into repairing due the real state, introducing flexible running systems in car-repairing industry as well.

Keywords: planning-warning repairing system, repairing due to the fact, flexible running system, new car generation. 
Вступ. Парк вантажних вагонів України морально та фізично застарів та потребує оновлення. Більше $80 \%$ парку вантажних вагонів на вітчизняних залізницях має наднормативний термін експлуатації. Застарілий та зношений парк вантажних вагонів не забезпечує в повній мірі потреби у перевезеннях вантажів, має недостатні на даний час техніко-економічні показники, потребує збільшення витрат на підтримання працездатності в експлуатації та суттєвого збільшення витрат на планові види ремонту, ДР та КР. Впровадженням вагонів нового покоління займаються провідні наукові організації та конструкторські бюро, велику роль у впровадженні таких вагонів відіграли ДНУЗТ (колишній ДІІТ), ПАТ «Азовмаш», ПАТ «КВБЗ», ПАТ «Дніпровагонмаш» та iн.

Постановка проблеми. При проектуванні та експлуатації нових вагонів треба намагатися домогтися від них максимального прибутку при підтриманні показників безпеки руху на високому рівні. При розрахунку собівартості одиниці пробігу вантажного вагона слід враховувати витрати на придбання, амортизацію, експлуатаційні витрати та витрати на ремонт. На жаль, не завжди вдається врахувати всі витрати, які супроводжують вантажний вагон за весь період його життєвого циклу, що призводить до незапланованих витрат та погіршення економічних показників вагонного господарства, на частку якого припадає до $11 \%$ поточних витрат.

Аналіз останніх досліджень і публікацій. Вдосконаленню організації ремонту рухомого складу, а саме вантажних вагонів присвячені публікації [1, 2]. Удосконаленню системи технічного обслуговування та ремонту вантажних вагонів присвячені публікації [3, 4].

Розглянуті публікації не в повній мірі враховують особливості вагонів нового покоління 3 підвищеними показниками надійності.

Основна частина. Реформування ПАТ «Українська залізниця» передбачає підвищення ефективності вагонного господарства, насамперед за рахунок зниження витрат на технічне обслуговування та ремонт вантажних вагонів при безумовному забезпеченні показників безпеки руху на високому рівні.

Досягнення цієї мети, в першу чергу, передбачає розвиток галузі за двома головними напрямками:

- вдосконалення технології i організації процесу ремонту та технічного обслуговування вантажних вагонів;

- вдосконалення конструкції деталей, вузлів та вагонів в цілому.

Перший напрямок розвитку можливий за умови підвищення ефективності ремонтної бази, запровадження нових технологій ремонту рухомого складу, вдосконалення системи ремонту вагонів, організації виробництва та комплексної механізації і автоматизації, підвищення культури виробництва та підвищення мотивації працівників.

Другий напрямок розвитку вимагає поповнення існуючого парку вагонів вагонами нового покоління, які мають збільшені показники надійності та модернізацію існуючих вагонів.

Вдосконалення існуючої системи ремонту вантажних вагонів повинно рухатися шляхом поступового переходу від планово-попереджувального ремонту (далі - ППР) на ремонт з врахуванням технічного стану кожного вагона. Діюча ППР система ремонту передбачає, що потрапляння вагона до ремонту відбувається в заздалегідь призначені моменти часу або при досягненні визначеного пробігу, незалежно від його технічного стану [5]. Переважна більшість вантажних вагонів повинна надходити в деповський ремонт згідно з критеріями, поданими на рис. 1. 

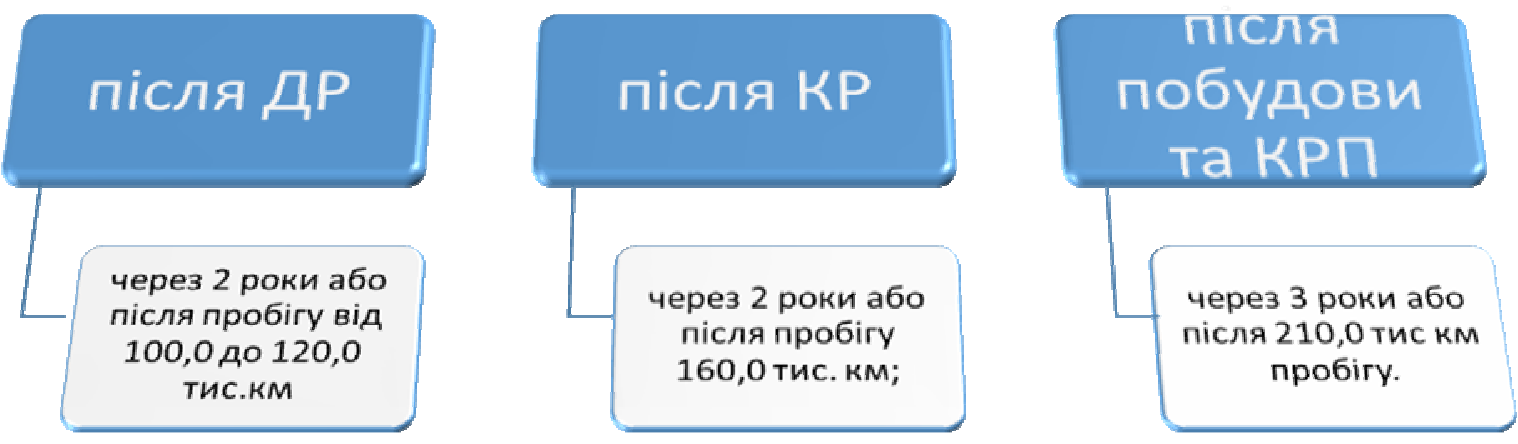

Рис. 1. Нормативи надходження до ремонту переважної більшості вантажних вагонів (планово-попереджувальна система ремонту)

Існуюча система ППР вантажних вагонів має багато недоліків, основні з яких такі:

- до поточного відчіпного ремонту потрапляє значна кількість вагонів (відсутність гарантій безвідмовної роботи вагонів в проміжку між ППР);

- значна кількість фінансових, матеріальних витрат та людських ресурсів на обслуговування і ремонт;

- застарілі нормативи, які регламентують потрапляння вагонів до ремонту, в своїй більшості розроблені за часів СРСР;

- зниження надійності ремонту через неякісний ремонт та пошкодження в експлуатації;

- не відображаються фактичні потреби у технічному обслуговуванні та ремонті конкретного вагона в залежності від умов його експлуатації, роду перевезеного вантажу, якості попереднього ремонту;

- недовикористання ресурсу деталей та вузлів вагона;

- значна кількість регламентованих ремонтних робіт виконується без особливої необхідності;

- проведення необгрунтованих ремонтів збільшує можливі помилки складання та монтажу;

- відмови можуть відбутися раніше розрахункового запланованого терміну. Це, зокрема, обумовлюється як невизначеністю i похибкою оцінок напрацювання до відмови, так i випадковою природою напрацювання до відмови.

Ремонт 3 урахуванням фактичного технічного стану передбачає, що потрапляння вагона до ремонту відбувається після досягнення, згідно 3 вимогами НТД, граничного стану вагона, подальша експлуатація якого загрожує безпеці руху або робить їі нерентабельною, тобто використовується принцип попередження відмов із забезпеченням максимально можливого напрацювання виробів при мінімальних експлуатаційних витратах [6]. Головною вимогою впровадження такого виду ремонту i технічного обслуговування $є$ впровадження у вагонному господарстві сучасних засобів технічного діагностування та прогнозування стану вагона і його вузлів.

Вагонобудівні та вагоноремонтні підприємства при плануванні робіт повинні враховувати конструктивні особливості вагонів нового покоління, а також розширювати свою спеціалізацію за рахунок ремонту спеціалізованих вагонів (рис. 2), які протягом останніх років показують стабільні позитивні тенденції збільшення попиту. Скорочення кількості вагоноремонтних підприємств, у зв'язку $з$ геополітичними змінами в державі (Крим та Донбас), також призводить до необхідності пошуку нових рішень в організації процесу ремонту. 


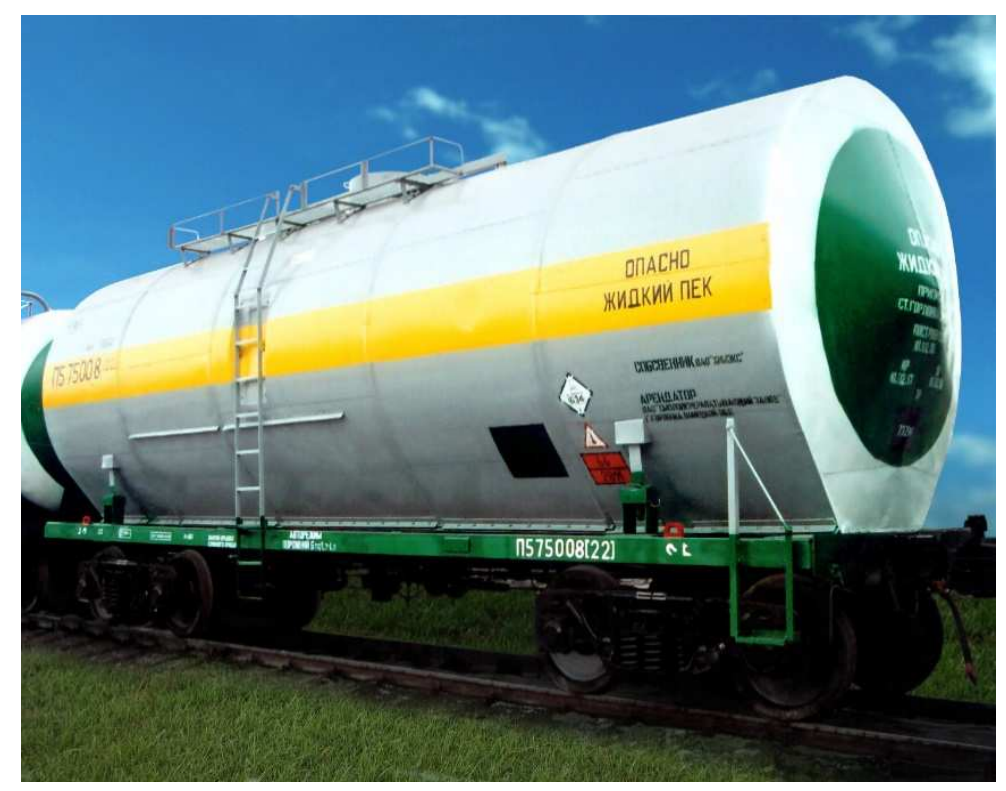

Рис. 2. Спеціалізований вагон-цистерна для пеку моделі 15-1534-03 побудови ПАТ «Азовмаш»

Існуючі вагоноремонтні депо передбачають тільки жорстку технологічну структуру. Така структура складається 3 послідовно з'єднаних елементів (позицій), i вихід будь-якого елементу 3 ладу відбивається на роботі всієї потокової лінії. 3 ростом інтенсивності експлуатації вагонів, а також виробництвом нових вагонів, що мають різні конструктивні відмінності, значно стала змінюватися і трудомісткість їх ремонту. А для «жорсткого» потоку необхідно, щоб час завершення виконання робіт на всіх позиціях відбувався б одночасно. Збій такту на будь-якій позиції в таких умовах негативно впливає на роботу всього потоку [7-9]. Новий рівень в розвитку організаційних форм вагоноремонтного виробництва - створення гнучких потокових систем. Сучасний рівень розвитку науки i техніки дозволяє їх успішно реалізувати. Основний акцент повинен бути зроблений на створенні вагоноремонтних підприємств, які могли б, використовуючи гнучкі потоки, ремонтувати кілька типів вагонів i виконувати різні види ремонту. За експертними оцінками, пропускна спроможність (продуктивність) вагоноремонтної дільниці зросте приблизно на 60-65\% [9].

Впровадження другого напряму можливе при поступовому оновленні парку вантажних вагонів вагонами нового покоління. В цих вагонах враховані недоліки конструкції попередніх моделей вагонів. Нові матеріали та сталі дозволяють продовжити строк служби металоконструкцій рами та кузова (котла) вагона. Технічні рішення щодо оптимізації конструкції рами та кузова сприяють зменшенню тари вагона при достатній міцності усієї конструкції. Модернізація візків передбачає спирання кузова на ковзуни, постановку у п'ятникові вузли та робочі поверхні гасників коливань зносостійких прокладок, перехід від типових буксових вузлів до касетних 3 адаптерами, застосування білінійного ресорного підвішування [10-13].

Зразки нової техніки проходять експлуатаційні випробування у замкнутих маршрутах Сартана-Інгулець для перевезення сипучих вантажів (рис. 3) [14, $15]$. 


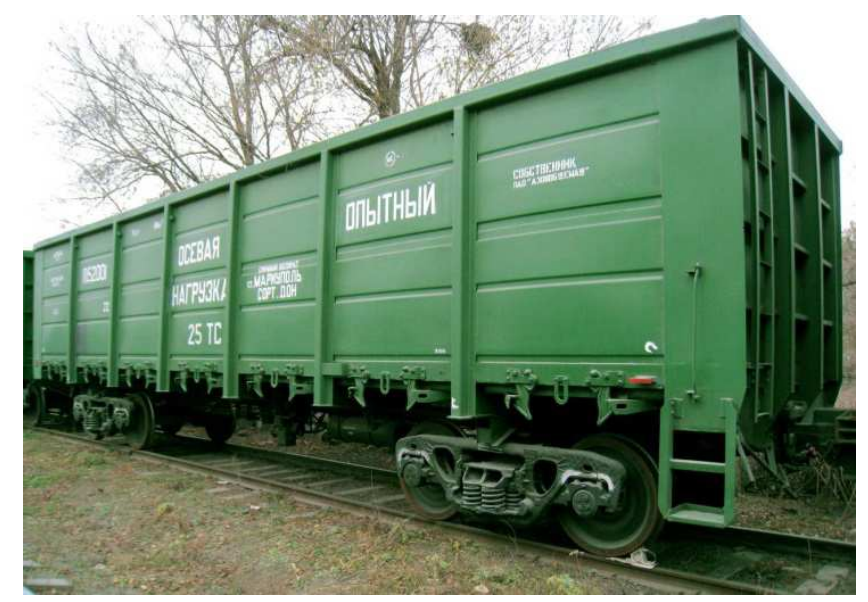

Рис. 3. Піввагон нового покоління побудови ПАТ «Азовмаш» 3 осьовим навантаженням 25 т

Результати дослідної експлуатації вагонів нового покоління, які мають деталі та вузли більш надійні, ніж попередні, дають можливість перегляду регламенту та періодичності технічного обслуговування і ремонту вантажних вагонів [16]:

- для усіх вагонів, у яких норматив пробігу після капітального ремонту складає 160,0 тис.км, встановити календарну тривалість використання, яка складатиме три роки (замість діючих двох років);

- вантажним вагонам, візки яких модернізовані $з$ використанням металевих або полімерних елементів у вузлах тертя, після деповського ремонту до наступного планового ремонту встановити норматив пробігу 160,0 тис. км, а календарну тривалість міжремонтного періоду встановити три роки;

- вантажним вагонам, візки яких модернізовані з використанням металевих або полімерних елементів у вузлах тертя, після капітального ремонту до наступного планового ремонту встановити норматив пробігу 210,0 тис. км, а календарну тривалість міжремонтного періоду встановити чотири роки.

Результати дослідної експлуатації дозволяють більш точно планувати періодичність ремонту вагонів 3 підвищеними показниками надійності.

Висновки. Впровадження вагонів нового покоління та нової системи ремонту й технічного обслуговування вантажних вагонів за фактичним станом дозволить скоротити витрати на їх експлуатацію та ремонт. Зростання продуктивності праці, покращення якості ремонту та скорочення простоїв вагонів в ремонті можливо при впровадженні гнучких потокових систем на вагоноремонтних підприємствах.

\section{Список використаних джерел}

1. Современная концепция депо для небольших парков подвижного состава [Текст] // Железные дороги мира. - 2007. - №3. - С. 60-63.

2. Сосунов, Н.Н. Повышение эффективности процессов эксплуатации и технического обслуживания подвижного состава в системе ремонтных предприятий отрасли [Текст] / Н.Н. Сосунов // Вісник Східноукраїнського національного університету ім. В. Даля. Луганск, 2006. - С. 219-223.

3. Старых, С.А. Повышение эффективности ремонта грузовых вагонов [Текст] / С.А. Старых // Железнодорожный транспорт. - 2007. - №8. - С. 24-27. 
4. Фалендиш, А.П. Аналіз робот вчених в області оптимізації системи технічного обслуговування і ремонту [Текст] / А.П. Фалендиш, О.В. Устенко, М.В. Володарець // Зб. наук. праць ДонІЗТ. - Донецьк: Вид-во ДонІЗТ, 2012. - Вип. 31. - С. 114-121.

5. Вагонное хозяйство [Текст]: учеб. для вузов / под ред. П.А. Устича. - М. : Маршрут, 2003. $-560 \mathrm{c}$.

6. Fagot, O. Maintenance du matériel roulant en Europe [Текст] / O. Fagot // La Vie du Rail International. - 2008. - № 4. - P. 12-15.

7. Мямлин, В.В. Исследование функционирования различных структурных вариантов гибких потоков для ремонта вагонов при помощи имитационного моделирования [Текст] / В.В. Мямлин // Вісник Дніпропетр. нац. ун-ту залізн. трансп. ім. акад. В. Лазаряна. Дніпропетровськ, 2014. - Вип. 3 (51).- С. 124-135.

8. Мямлин, В.В. Повышение надёжности работы вагоноремонтных потоков за счёт формирования их гибкости [Текст] / В.В. Мямлин, С.В. Мямлин // Проблемы безопасности на транспорте: матер. VI междунар. науч.-практ. конф. - Гомель: БелГУТ, 2012. - С.92-93.

9. Мямлин, В.В. Теоретические основы создания гибких поточных производств для ремонта подвижного состава [Текст]: монография / В.В. Мямлин. - Днепропетровск: ЧФ «Стандарт-Сервис», 2014. - 380 с.

10. Савчук, О.М. Вагонний парк [Текст]: навч. посібник для вузів / О.М. Савчук. Харків: Техностандарт, 2010. - 200 с.

11. Бубнов, В.М. Конструктивные особенности полувагона нового поколения с осевой нагрузкой 25 т [Текст] / В.М. Бубнов, С.В. Мямлин, Е.А. Фейерэйзен // Проблеми та перспективи розвитку залізничного транспорту: тези доп. 70-ї міжнар. наук.-практ. конф. Дніпропетровськ, 15. 04 - 16. 04. 2010 / ДНУЗТ. Схід. наук. центр трансп. акад. України. Дніпропетровськ: ДНУЗТ, 2010. - С. 66-67.

12. Bubnov, V.M. Dynamic performance of freight cars on bogies model 18-1711 / V.M. Bubnov, S.V. Myamlin, N.B. Mankevych [Текст] // Наука та прогрес транспорту. Вісн. Дніпропетр. нац. ун-ту залізн. трансп. - 2013. - № 4 (46). - С. 118-126.

13. Pavels Gavrilovs, Dijs Sergejevs Resisting momentum in the abutment to rotating of freight car bogie [Текст] / Transport Problems: an International Scientific Journal. - 2008. - 3 (4 part 2). - P. 65-71.

14. Савчук, О.М. Эксплуатационные испытания полувагонов нового поколения [Текст] / О.М. Савчук, Л.А. Мурадян, В.К. Бруякин [и др.] // Вагонный парк. - 2009. - № 5/6 -7/8. C. 30-32. - C. 8-11.

15. Мурадян, Л.А. К вопросу о планах испытаний надежности механических систем [Текст] / Л.А. Мурадян, В.Ю. Шапошник // Зб. наук. праць Укр. держ. ун-ту залізнич. трансп. - Харків: УкрДУЗТ, 2015. - Вип. 157. - С. 119-128.

16. Мельничук, В.О. Удосконалення системи технічного обслуговування та ремонту вантажних вагонів [Текст] / В.О. Мельничук, С.В. Мямлін, І.В.Ісопенко, В.В. Мямлін // Зб. наук. праць ДонІЗТ. - 2010. - Вип. 22. - С. 101-108.

Рецензент д-р техн. наук, професор С.В. Мямлін

Бубнов Валерій Михайлович, Генеральний директор ТОВ «ГСКБВ» ПАТ «Азовмаш».

E-mail: bubnov@azovmash.com.

Мурадян Леонтій Абрамович, канд. техн. наук, доцент, кафедра вагонів та вагонного господарства, Дніпропетровський національний університет залізничного транспорту імені академіка В. Лазаряна. Тел.: (056) 373-15-19. E-mail: leon59@bk.ru, ORCID 0000-0003-1781-4580.

Шапошник Владислав Юрійович, інженер I кат., галузева науково-дослідна лабораторія «Вагони», Дніпропетровський національний університет залізничного транспорту імені академіка В. Лазаряна. Тел.: (056) 373-15-19. E-mail: ORCID 0000-0003-4701-6491. 
Манкевич Микола Борисович, завідуючий бюро ТОВ «ГСКБВ» ПАТ «Азовмаш». E-mail: bubnov@azovmash.com.

Bubnov V., General Designer «GSKBV named after V. M. Bubnov», Mashinostroiteley Sq, 1, Mariupol, Ukraine, 87535. Tel. +38 (0629) 5186 43. E-mail bubnov@azovmash.com.

Muradian L., candidate of techn. sciences department «Car and Car Facilities» of Dnipropetrovsk National University of Railway Transport named after academician V. Lazaryan, Lazaryan Str., 2, 49010,

Dnepropetrovsk, Ukraine. Tel. +38 (056) 37315 19. E-mail leon59@bk.ru, ORCID 0000-0003-1781-4580. Shaposhnyk V., Wagons Laboratory of Dnipropetrovsk National University of Railway Transport named after academician V. Lazaryan, Lazaryan Str., 2, 49010, Dnepropetrovsk, Ukraine. Tel. +38 (056) 3731519. ORCID 0000-0003-4701-6491.

Mankevych N.B. LTD «GSKBV named after V. M. Bubnov», Mashinostroiteley Sq, 1, Mariupol, Ukraine, 87535. Tel. +38 (0629) 5186 43. E-mail bubnov@azovmash.com.

Прийнята 09.03.2016 р. 